\title{
DO WORKERS' HEALTH SURVEILLANCE EXAMINATIONS FULFILL THEIR OCCUPATIONAL PREVENTIVE OBJECTIVE? ANALYSIS OF THE MEDICAL PRACTICE OF OCCUPATIONAL PHYSICIANS IN CATALONIA, SPAIN
}

\section{MARI CRUZ RODRÍGUEZ-JAREÑ $0^{1,2}$, EMILIA MOLINERO ${ }^{3}$, JAUME DE MONTSERRAT ${ }^{3}$, ANTONI VALLÈ ${ }^{4}$, and MARTA AYMERICH ${ }^{5,6}$}

${ }^{1}$ University of Girona, Catalonia, Spain

School of Medicine, Department of Medical Sciences

${ }^{2}$ Integrated Baix Empordà Health Services, Palamós, Girona, Spain

Occupational Health Service

${ }^{3}$ Ministry of Enterprise and Labour, Government of Catalonia, Spain

Occupational Health and Safety Institute

${ }^{4}$ University of Barcelona, Catalonia, Spain

School of Medicine, Department of Public Health

${ }^{5}$ University of Girona, Catalonia, Spain

School of Medicine, Department of Medical Sciences, TransLab Research Group

${ }^{6}$ Open University of Catalonia, Catalonia, Spain

Health Sciences Studies

\begin{abstract}
Objectives: Although routine workers' health examinations are extensively performed worldwide with important resource allocation, few studies have analyzed their quality. The objective of this study has been to analyze the medical practice of workers' health examinations in Catalonia (Spain) in terms of its occupational preventive aim. Material and Methods: A cross-sectional study was carried out by means of an online survey addressed to occupational physicians who were members of the Catalan Society of Safety and Occupational Medicine. The questionnaire included factual questions on how they performed health examinations in their usual practice. The bivariate analysis of the answers was performed by type of occupational health service (external/internal). Results: The response rate was $57.9 \%(\mathrm{~N}=168)$, representing $40.3 \%$ of the reference population. A high percentage of occupational physicians had important limitations in their current medical practice, including availability of clinical and exposure information, job-specificity of tests, and early detection and ap-
\end{abstract}

Funding: the paper has been partially funded by a Fundación Prevent Grant in Innovation and Development in Occupational Risk Prevention (VII Edition, 2012). Grant manager: Mari Cruz Rodríguez-Jareño, M.D.

Received: January 31, 2016. Accepted: July 25, 2016.

Corresponding author: M.C. Rodríguez-Jareño, University of Girona, School of Medicine, Department of Medical Sciences, Emili Grahit 77, 17071 Girona, Spain (e-mail: maricruz.rodriguez@udg.edu). 
propriate management of suspected occupational diseases. The situation in external occupational health services - that covered the great majority of Catalan employees - was worse remarkably in regard to knowledge of occupational and nonoccupational sickness absence data, participation in the investigation of occupational injuries and diseases, and accessibility for workers to the occupational health service. Conclusions: This study raises serious concerns about the occupational preventive usefulness of these health examinations, and subsequently about our health surveillance system, based primarily on them. Professionals alongside health and safety institutions and stakeholders should promote the rationalization of this system, following the technical criteria of need, relevance, scientific validity and effectiveness, whilst ensuring that its ultimate goal of improving the health and safety of workers in relation to work is fulfilled. Other countries with similar surveillance systems might be encouraged by our results to assess how their practices fit the intended purpose. Int J Occup Med Environ Health 2017;30(6):823-848

Key words:

Occupational medicine, Occupational health services, Workers' health surveillance, Periodical medical examinations, Medical practice, Preventive usefulness

\section{INTRODUCTION}

According to the International Labour Office (ILO), the central purpose of worker's health surveillance is the primary prevention of occupational and work-related diseases and injuries, and health examinations play a very important role, not only in primary but also in secondary prevention, through early detection. Workers' health surveillance should be based on sound ethical and technical practices, and procedures in a particular program must meet, clearly and demonstrably, four criteria: need, relevance, scientific validity and effectiveness [1].

In many countries, it is an obligation of all employers to provide occupational health coverage for their employees. In Spain, the main health and safety law [2], a transposition of European Framework Directive 89/391/EEC [3], requires companies to offer appropriate health surveillance to all their employees. This is mostly done in the form of periodic health examinations which are voluntary for workers, with the exception of certain regulated occupational risks like noise, lead, silica, asbestos, etc. The same law states that health examinations should be job-specific (i.e., in relation to the occupational risks) and should serve as a key instrument for prevention. Workers' health surveillance is defined as a preventive activity, and health examinations are performed as one of the available tools to "investigate and analyze the possible relationship between exposure to occupational hazards and damage to health, with the aim to propose measures to improve working conditions and the working environment" [4]. Workers' health surveillance activities in Spain are performed by occupational health professionals within internal or external occupational health services (OHS). Companies may either directly employ physicians and other members of the team (occupational nurses, hygienists, safety engineers, etc.) to create their own internal OHS, or contract the services from the external OHS: a private external provider that procures the physicians and the rest of professionals.

The role of reaching final diagnosis and providing treatment for occupational injuries and diseases lies with the Social Security system through occupational injuries and diseases insurers, to which physicians from the OHS refer suspected cases. Non-work-related issues are handled by the publicly financed National Health System. In Catalonia, $71.1 \%$ of companies have the external OHS, covering $83.7 \%$ of salaried employees [5].

In 2013, 28.2\% of Catalan workers had a health examination for health surveillance purposes [6], which yielded approximately 700000 examinations, given a salaried population of 2471100 [7]. Although no official data exists for Spain as a whole, assuming a similar ratio could be applied to a national salaried population of 14069100 in 2013 [7], nearly 4 million employees should be expected to attend for a health examination in the country every year. As any 
form of screening, this extensively performed preventive activity should respond to the still valid [8] Wilson and Jungner criteria [9], and is not free of unwanted side-effects, such as undue anxiety associated with false positives, re-testing, over-diagnosis and medicalization [10-13]. Given the significant allocation of human and material resources, it should be based on scientific evidence and conducted effectively.

However, according to a previous study, a high percentage of occupational health professionals in Catalonia hold a negative opinion about the efficiency and preventive usefulness of the workers' health examinations performed in our theoretical job-specific health surveillance system [14]. These professionals largely described health examinations as not job-specific, inefficient and not evidence-based, and the health surveillance system as not cost-effective, not meeting the goal of early detection of health damage related to work, and not contributing to the improvement of the occupational risk prevention system. The situation seemed to be worse in external than in the internal OHS. These results warranted further investigation.

The objective of this study has been to describe and analyze the current medical practice of the workers' health examinations in Catalonia, mainly in terms of its occupational preventive aim, whilst searching for any potential differences by type of occupational health service.

\section{MATERIAL AND METHODS}

\section{Study population and survey design}

The study was of a cross-sectional design. The reference population was as a whole comprised of physicians working in the OHS in Catalonia and performing health examinations in their usual practice (Figure 1). There is not an official census, but indirect data [6] allowed to estimate that 417 physicians met those inclusion criteria. According to this data, the sample size required to estimate a proportion with an error of $\pm 5 \%$ and a $95 \%$ confidence interval $(\mathrm{CI})$ under the assumption of maximum uncertainty



SCSMT - Societat Catalana de Seguretat i Medicina del Treball (the Catalan Society of Safety and Occupational Medicine).

Fig. 1. Flowchart of reference population, study population and sample of occupational physicians participating in a survey about their usual medical practice, Catalonia, Spain, 2011

$(\mathrm{p}=\mathrm{q}=0.5$ ) would be 200 physicians [15]. The study population consisted of the occupational physicians members of the "Societat Catalana de Seguretat i Medicina del Treball" (the Catalan Society of Safety and Occupational Medicine - SCSMT) which met the above mentioned inclusion criteria ( $\mathrm{N}=290$, estimated).

A questionnaire was developed taking into account the objectives of the study and the scientific and legal aspects that would subsequently be used to analyze the responses. The translated version of the questionnaire is available online in the Table 1 . To test feasibility and content validity, a pilot test with professionals $(\mathrm{N}=14)$ was conducted which helped refine the final questionnaire. No issues 


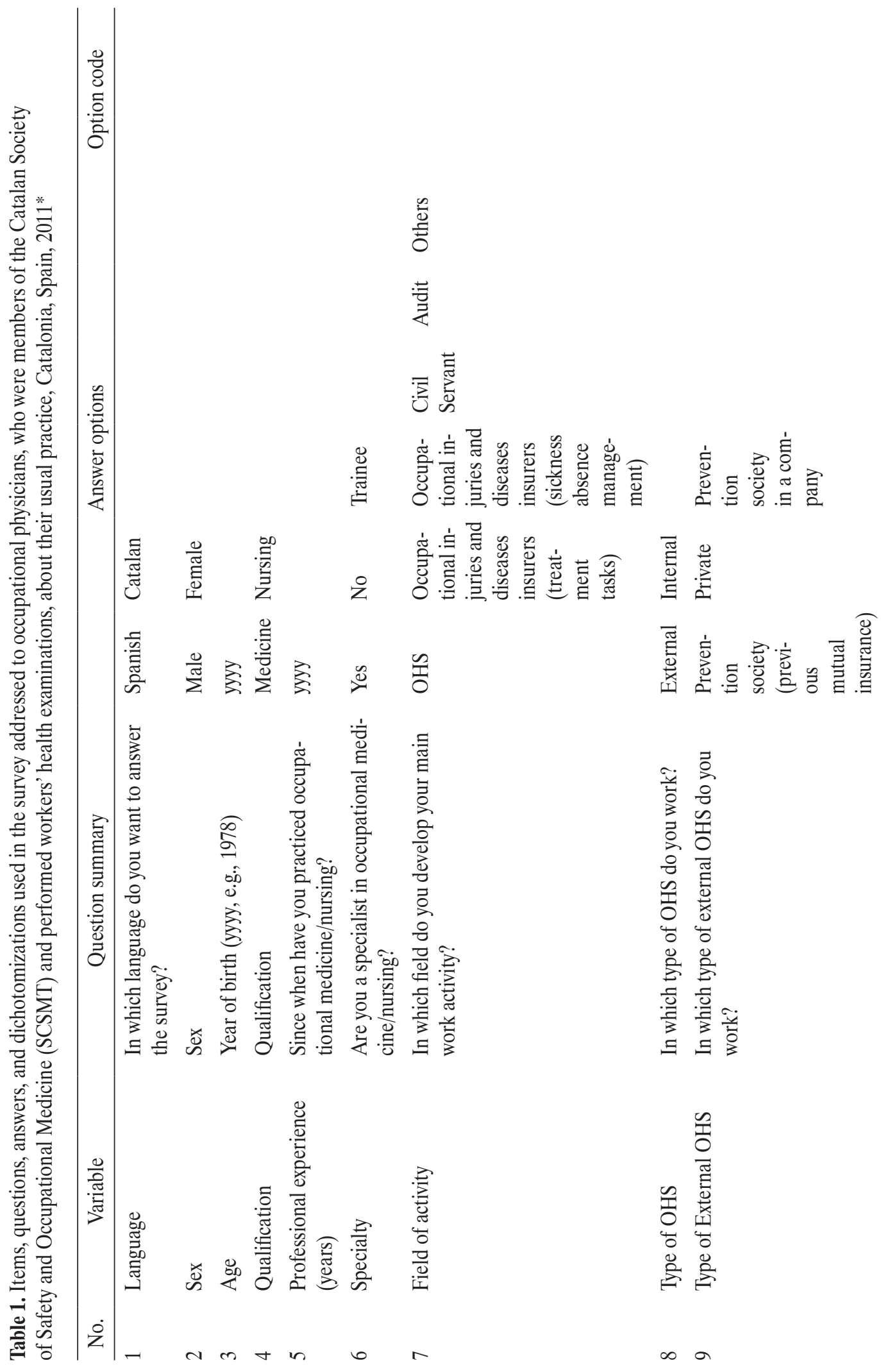



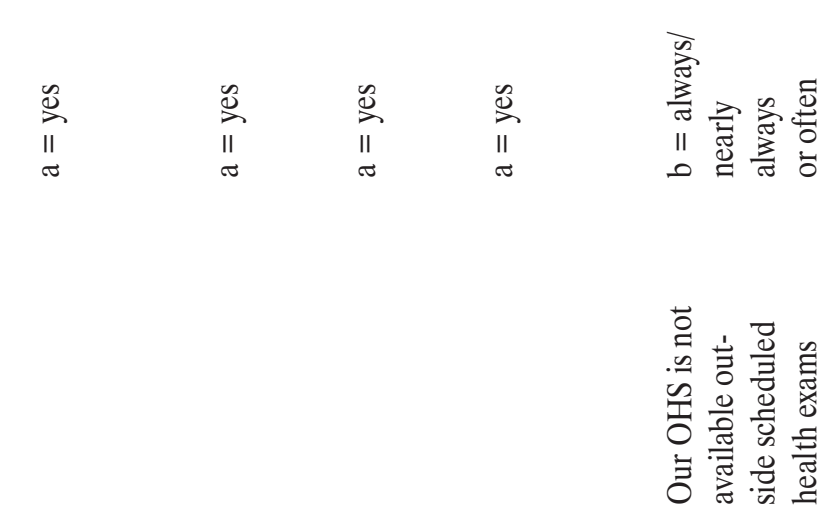

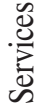

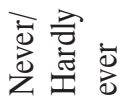



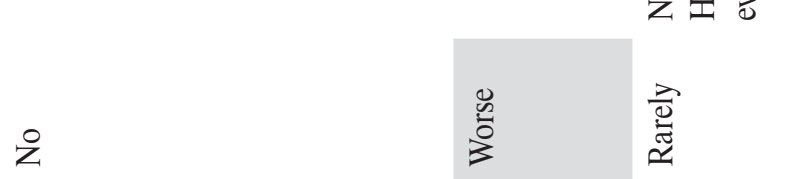

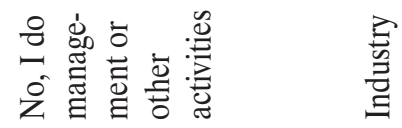

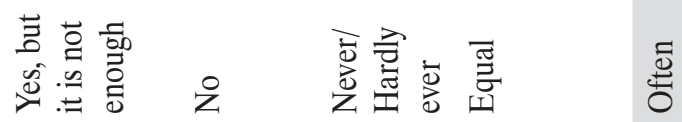

$\stackrel{\infty}{2}$



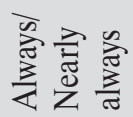

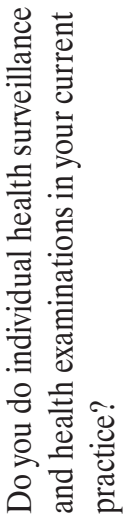

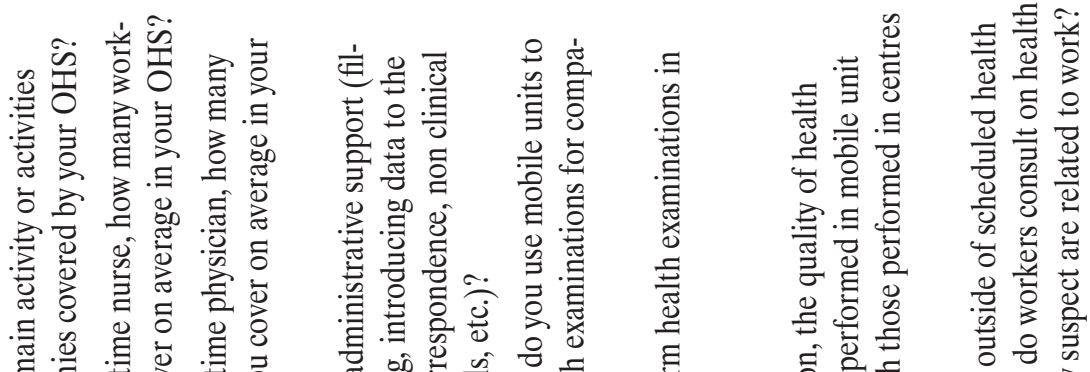

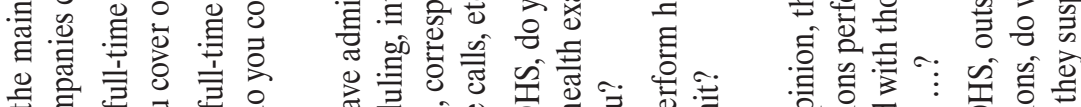

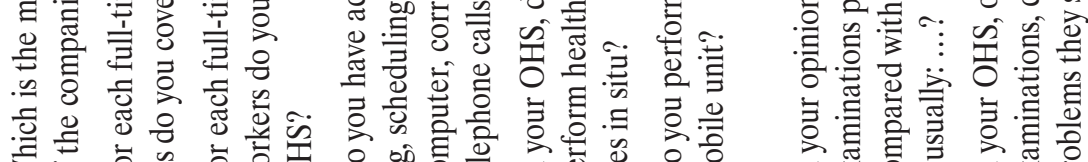

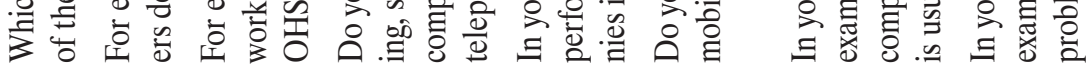

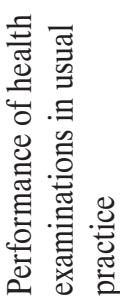

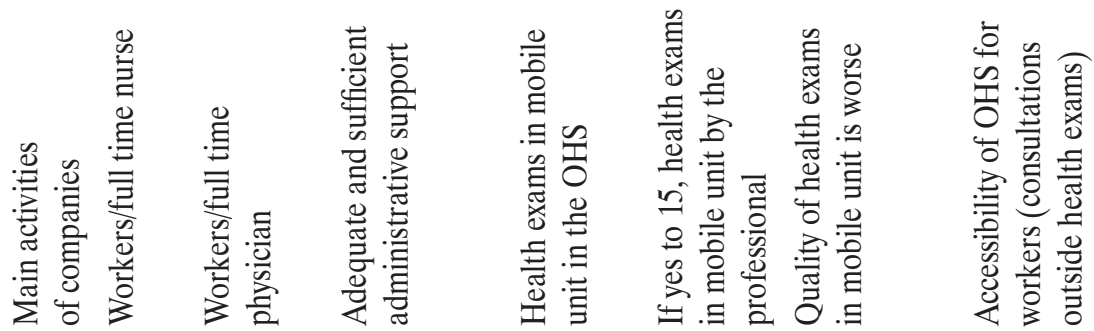

으

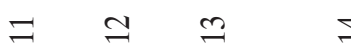

士

n

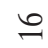

=

$\stackrel{\infty}{-1}$ 


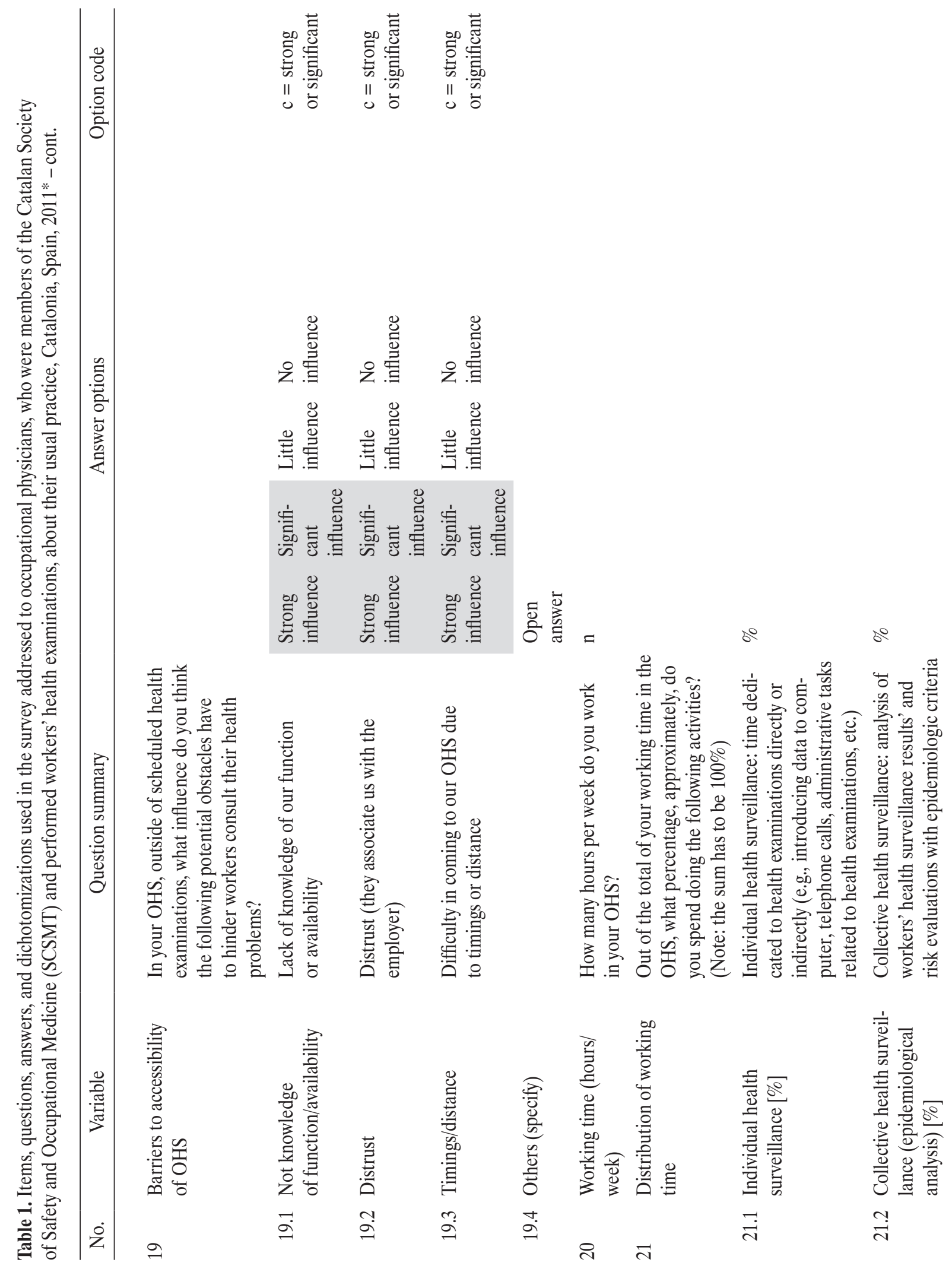




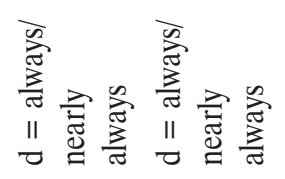

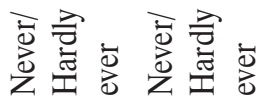

竞 意

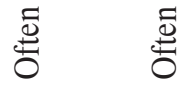

be $\Rightarrow=\Rightarrow$

se de se se se se se

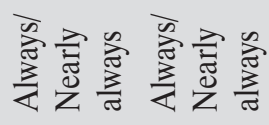

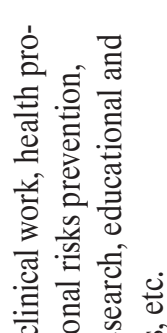
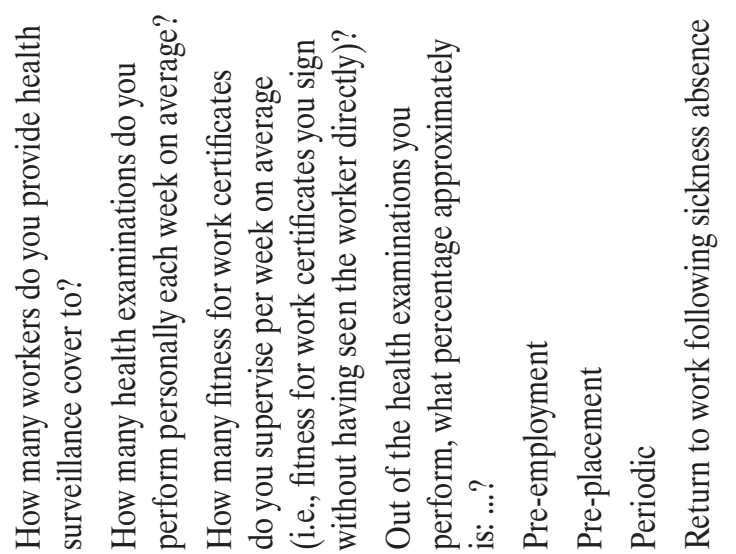

高



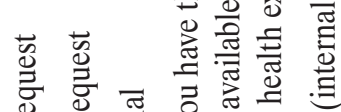

i 0 .

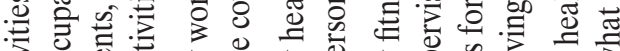



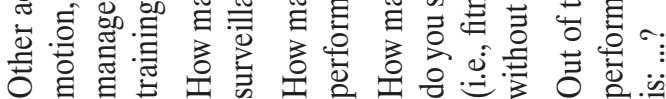

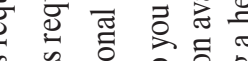

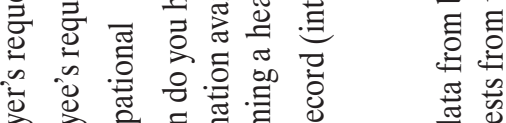

ठั

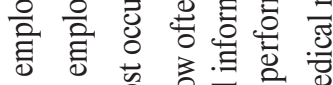

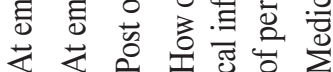

焉离兽

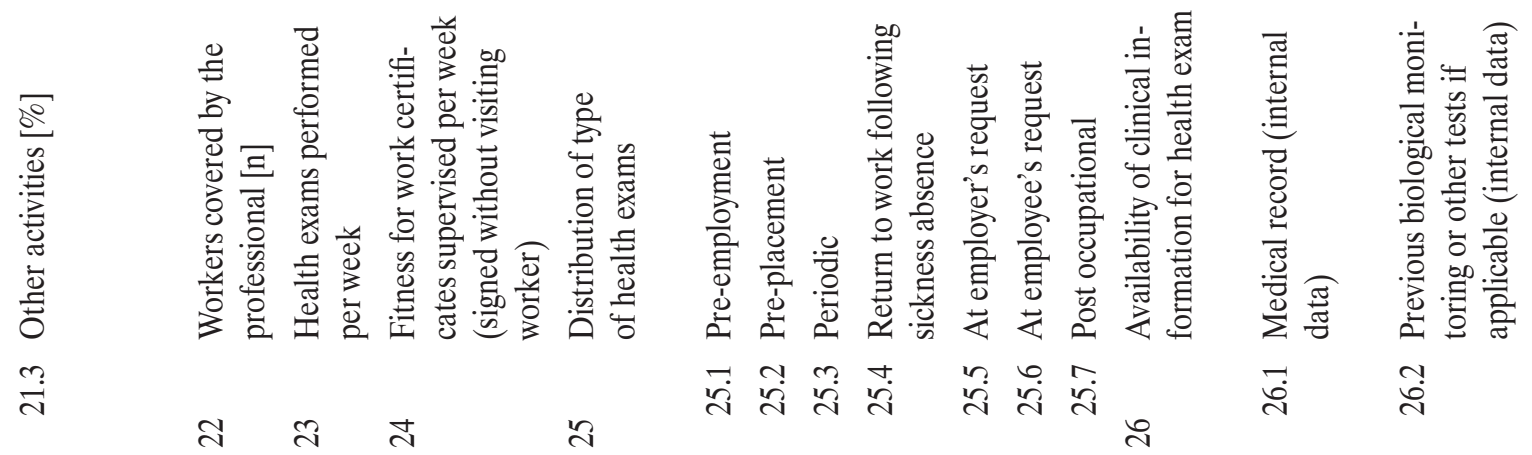









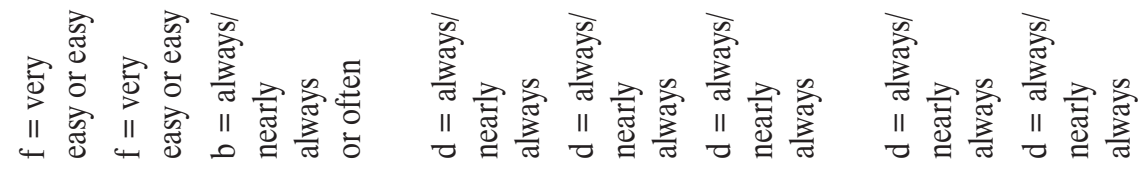

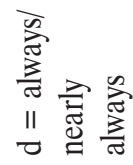

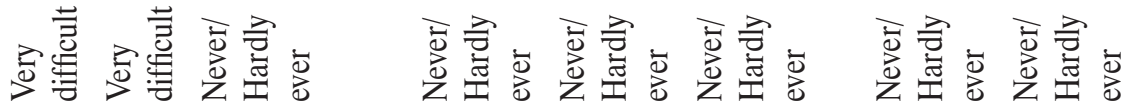

言棓离

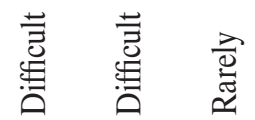

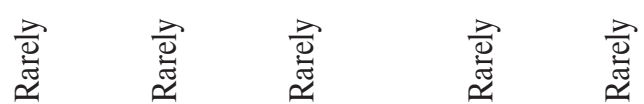



虔密离

政 矛



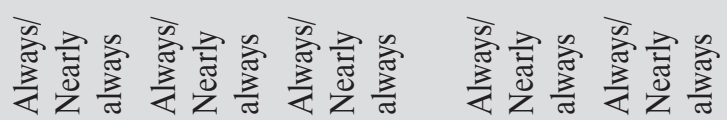

$\stackrel{\text { ֻี }}{0}$

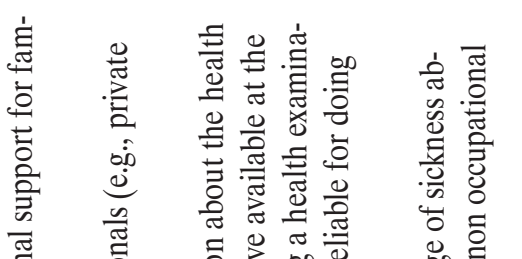



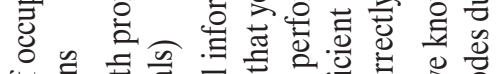

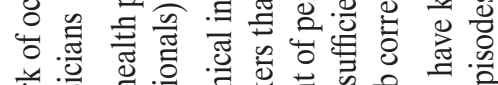

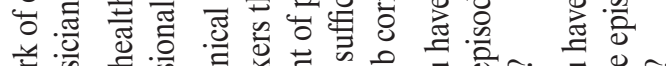



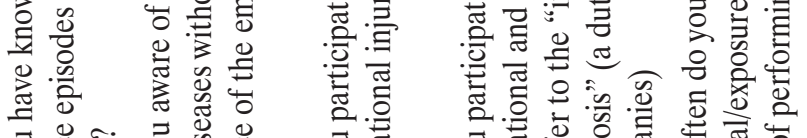

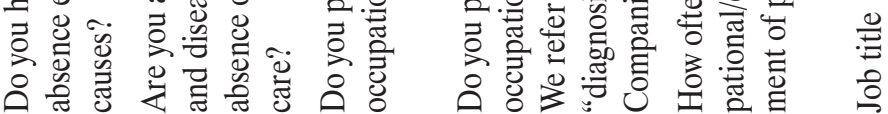

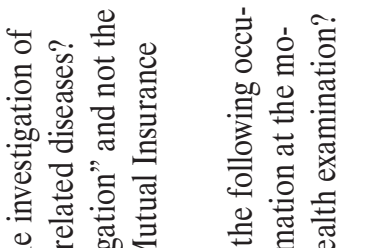



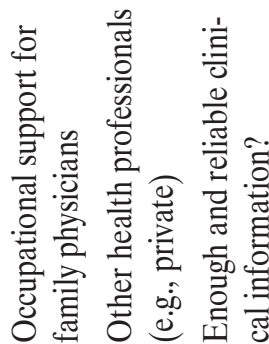

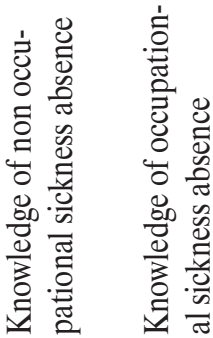

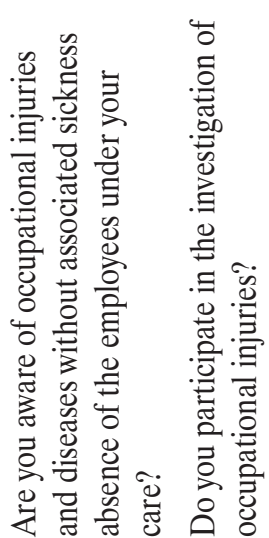

กั ฉั่

요

ल ले ल

m

$\stackrel{n}{n}$

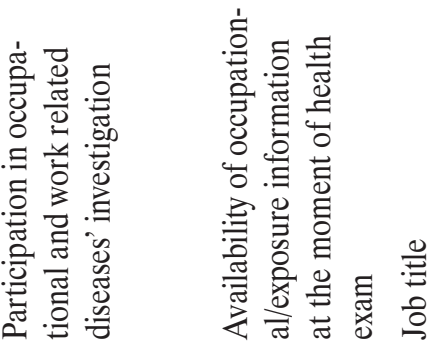

గ










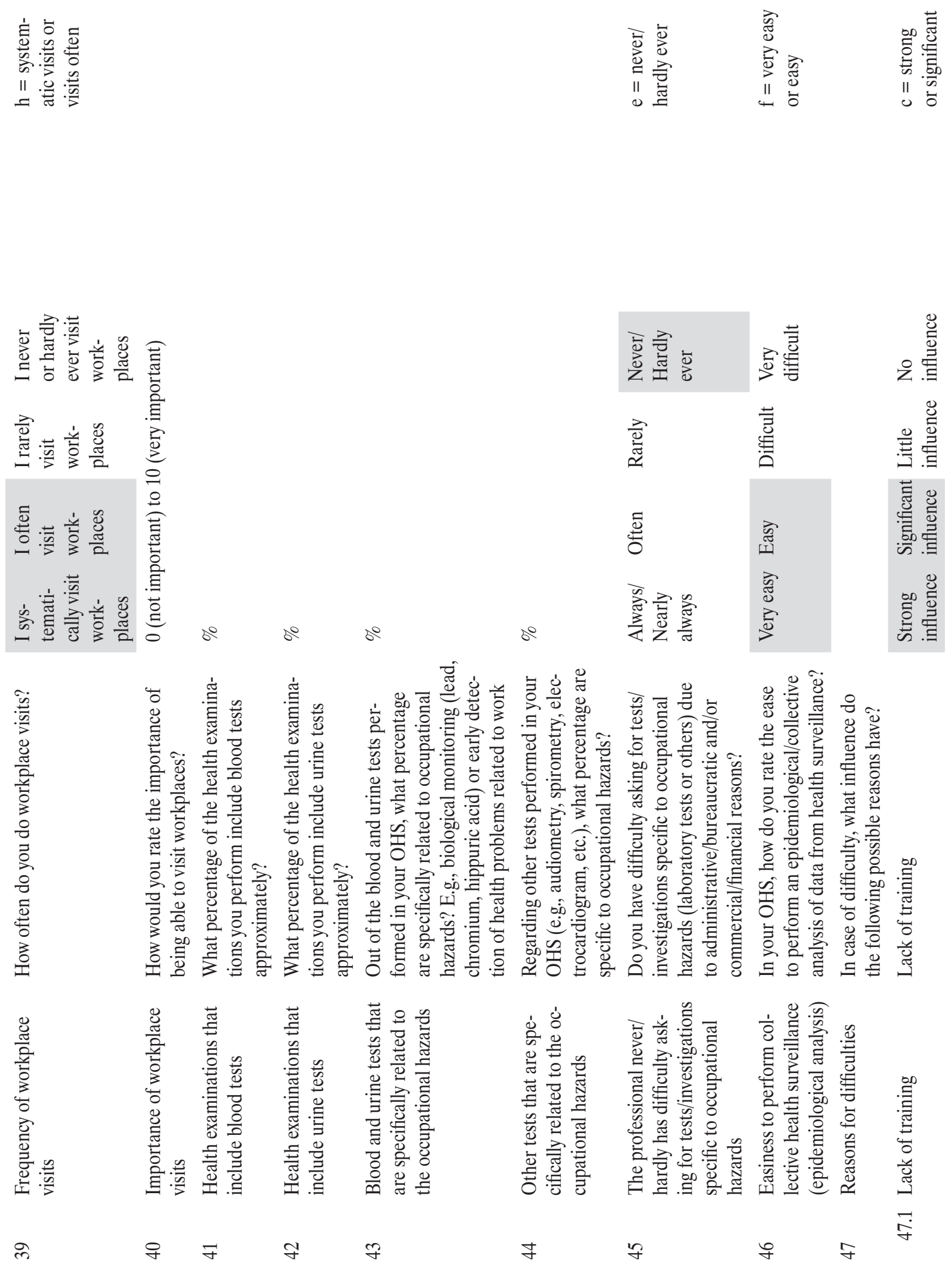


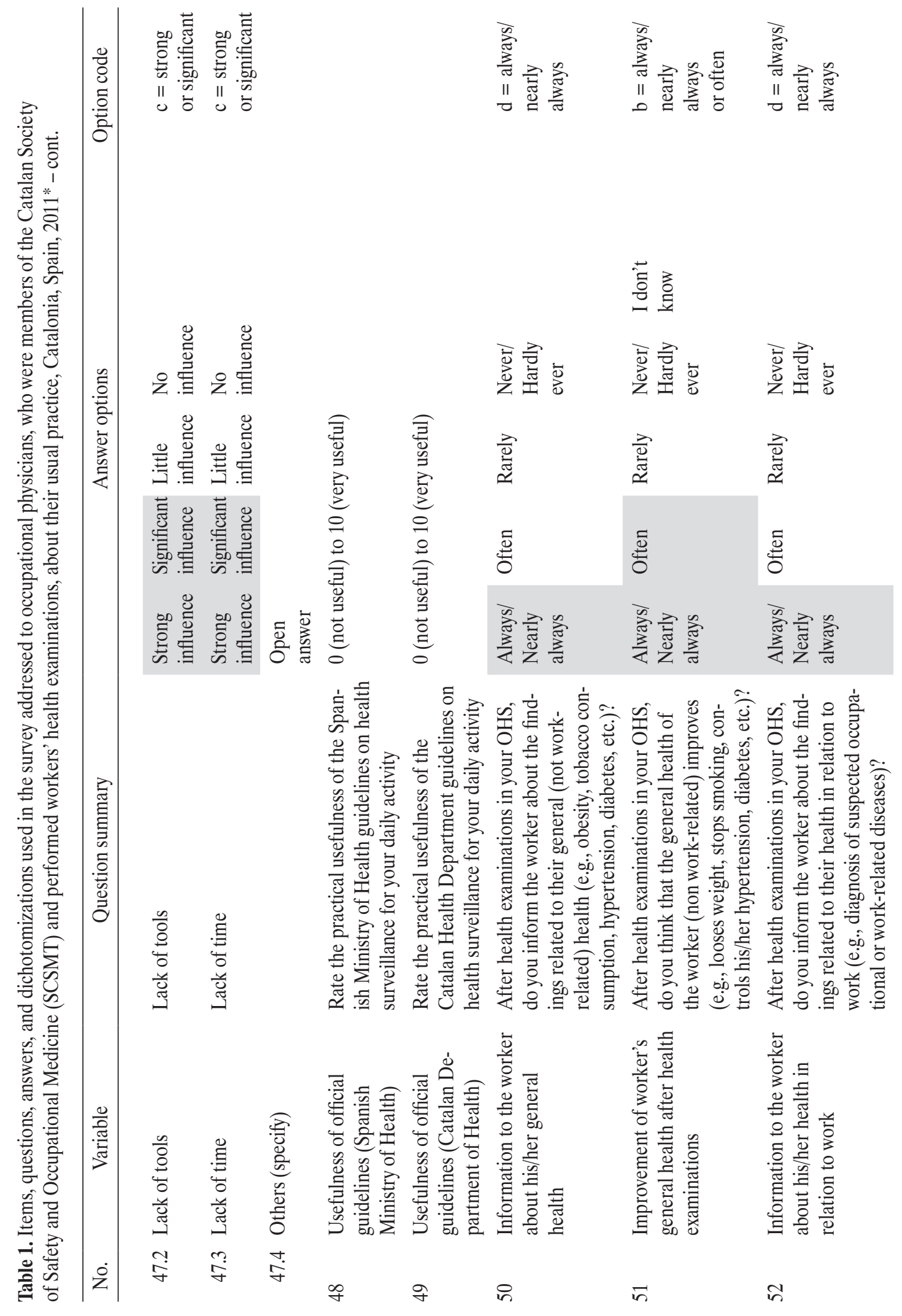



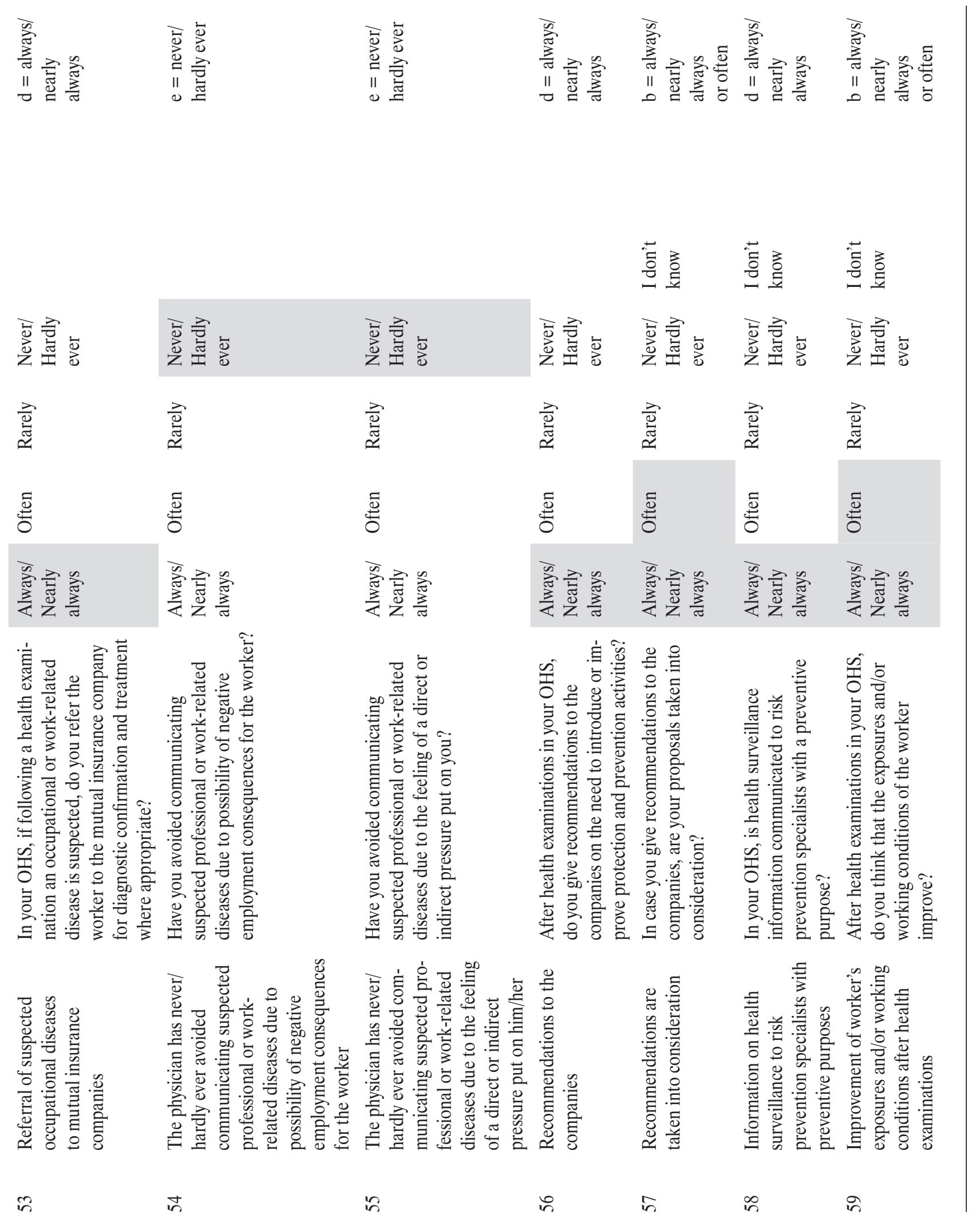







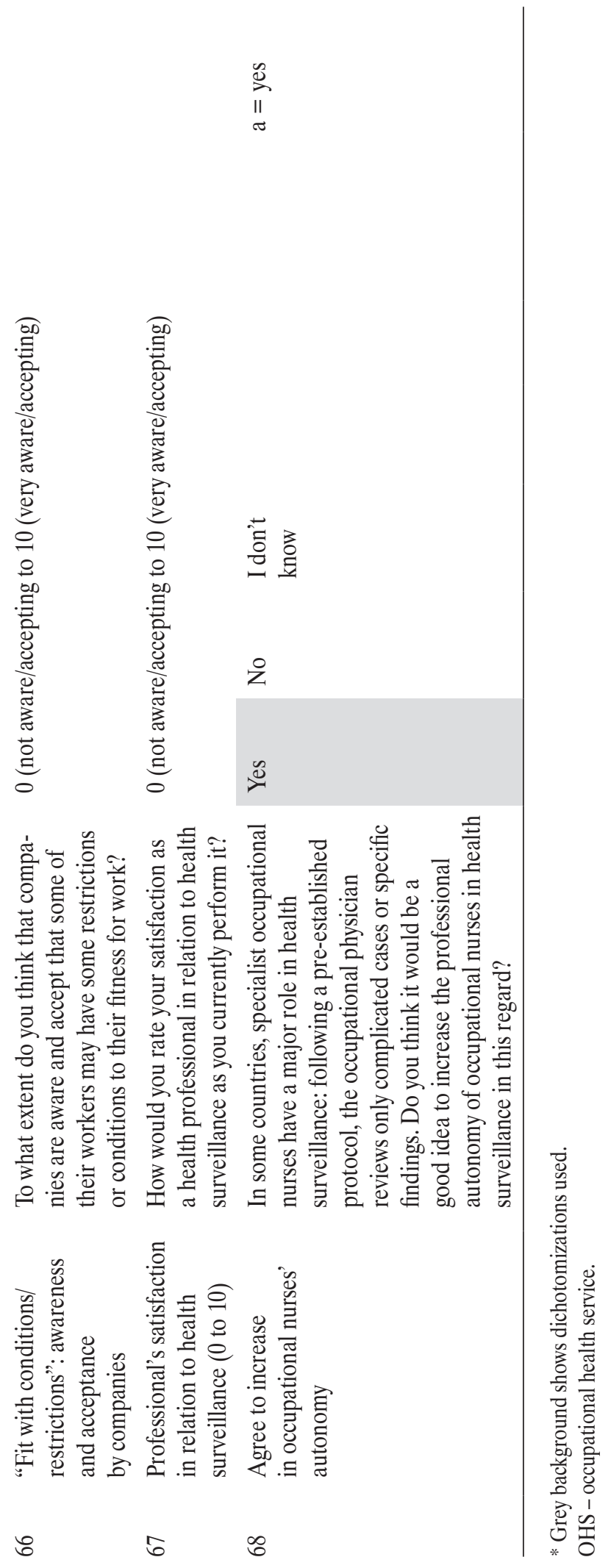


were raised in face-validity and no ceiling or floor effects were observed.

Data was collected from voluntary participants through an online self-administered questionnaire in September 2011. All the information, including the objective of the study, was sent by the administrative staff of the SCSMT. The researchers remained blind to the list of potential and actual participants throughout the process. The survey was anonymous and participation implied consent. The sample consisted of those professionals responding to the survey who chose the option "Yes, I do health examinations in my usual practice" and, therefore, those who worked in the OHS but did only management were excluded.

\section{Study variables}

Participants' characteristics

Participants' age (years old), sex (male/female), and the type of OHS (internal/external) were given.

\section{Medical practice}

A total of 57 factual questions were asked to occupational physicians about how they performed health examinations in their usual medical practice. Questions were worded in a direct and neutral manner and, whenever possible, numerical questions were asked; for frequency questions, Likert's scales were used with five categories of response, appropriately organized and scored. Health examination was defined as the clinical and occupational anamnesis together with medical examinations and tests performed by the occupational health professional to each individual employee in the context of the activities of health surveillance with the aim of establishing a possible relationship between the health and the working conditions of the subject.

This study explores surveillance examinations in general, regardless of the specific surveillance program addressed. The areas explored included the following: general or- ganizational aspects including workload and tasks; availability of clinical and occupational exposure information; job-specificity of the tests used (i.e., were the tests related to specific occupational hazards?); communication issues (among the members of the OHS team, and with other health professionals and organisms); early detection and appropriate management of suspected cases of occupational diseases; knowledge of occupational and non-occupational sickness absence data; participation in the investigation of occupational injuries and diseases; accessibility for workers to the OHS; and professional independence. Likert-type scales with 4 or 5 categories, numeric text boxes for continuous variables and open boxes for comments were used for the answers. For categorical items, categories were dichotomized. In most cases, the first two positive categories of answer were grouped together against all the rest (e.g., "always/nearly always or often" against "rarely or never/hardly ever"). For those variables considered essential to guarantee a correct medical practice, the extreme option was chosen (e.g., "always/nearly always"). Items of the questionnaire and answer options, together with their dichotomizations, are available online in the Table 1.

\section{Data analysis}

The univariate analysis: means were calculated for the quantitative variables, and distribution of frequencies of categories for categorical variables (valid percentage), together with $95 \%$ CI for both.

The bivariate analysis by the type of OHS: for the quantitative variables the Student-Fisher t-test for the comparison of means of independent samples (level of significance $\alpha=0.05$ ) was used; means' differences and their 95\% CIs were also calculated. For categorical variables, the prevalence and the difference in prevalence were calculated, as was their $95 \%$ CI.

Statistical analyses were performed with the SPSS 15.0 software package for Windows. 


\section{RESULTS}

Out of the estimated 290 physicians that fulfilled the inclusion criteria, $168(57.9 \%)$ responded the survey, representing $40.3 \%$ of the reference population (total estimated physicians performing workers' health examinations in Catalonia). The final sample had absolute precision values of $\pm 7.5 \%$ for a confidence level of $95 \%$ under the assumption of maximum uncertainty $(\mathrm{p}=\mathrm{q}=0.5)$. No item had a percentage of missing values higher than $11 \%$.

Out of the 168 participants, $47.6 \%$ worked in the external OHS $(\mathrm{N}=80)$ and $52.4 \%$ in internal services $(\mathrm{N}=88)$. The average age was 47.3 years old (range: $30-62$ years old) and $59.5 \%$ were female $(\mathrm{N}=100)$. No statistically significant differences were observed when compared with the distribution of occupational physicians members of the SCSMT as a whole (Table 2).

As shown in the Table 3, occupational physicians worked an average $36.8 \mathrm{~h} /$ week (median: 38), and spent between $64 \%$ (internal) and $84 \%$ (external) of their working hours in activities related to health surveillance (either in- dividual and/or collective). Large differences were found regarding workload in relation to individual health surveillance: health professionals from the external OHS dedicated more time, did 2.5 times more health examinations and had nearly 3 times more workers assigned to them (3709 workers/full-time physician vs. 1353 for those in internal services). Both types of the OHS shared a 1:1 physician/nurse ratio and less than half of participants had adequate and sufficient administrative support.

Accessibility of workers to the external OHS was low, with $26 \%$ of employees making consultations outside health examinations for health problems possibly related to work, compared to $90 \%$ in internal services.

Most health examinations performed were periodic and included blood (96\% for external, $88 \%$ for internal) and urine tests (87\% external, $65 \%$ internal); however, physicians stated that these and other tests (e.g., urine or blood exposure markers, audiometry, spirometry, etc.) were specifically related to occupational hazards in less than a half of the cases.

Table 2. Sociodemographic and professional characteristics of occupational physicians, who were members of the Catalan Society of Safety and Occupational Medicine (SCSMT), performed workers' health examinations, and participated in the survey about their usual practice in comparison with all members of the SCSMT, Catalonia, Spain, 2011

\begin{tabular}{|c|c|c|c|c|c|c|c|}
\hline \multirow{3}{*}{ Characteristics } & \multicolumn{7}{|c|}{ Members of SCSMT } \\
\hline & \multicolumn{3}{|c|}{$\begin{array}{l}\text { survey participants* } \\
\quad(\mathrm{N}=168)\end{array}$} & \multicolumn{4}{|c|}{$\begin{array}{c}\text { total } \\
(\mathrm{N}=539)\end{array}$} \\
\hline & $\mathrm{n}(\%)$ & $95 \% \mathrm{CI}$ & M & $\mathrm{n}(\%)$ & M & MD & $95 \% \mathrm{CI}$ \\
\hline \multicolumn{8}{|l|}{ Sex } \\
\hline male & $68(40.5)$ & $33.3-48.0$ & & $226(41.9)$ & & & \\
\hline female & $100(59.5)$ & $52.0-66.7$ & & $313(58.1)$ & & & \\
\hline \multicolumn{8}{|l|}{$\begin{array}{l}\text { Type of occupational } \\
\text { health service }\end{array}$} \\
\hline internal & $88(52.4)$ & $44.9-59.8$ & & $183(59.6)$ & & & \\
\hline external & $80(47.6)$ & $40.2-55.1$ & & $124(40.4)$ & & & \\
\hline Age [years] & & & 47.28 & & 48.24 & 0.961 & $-0.532-2.455$ \\
\hline
\end{tabular}

$\mathrm{CI}$ - confidence interval; $\mathrm{M}$ - mean; MD - mean difference.

$*$ Response rate $=57.9 \%$ (168 of 290 physicians that fulfilled the study inclusion criteria). 
Table 3. Time spent to health surveillance at the workplace, workload and tasks of occupational physicians, who were members of the Catalan Society of Safety and Occupational Medicine (SCSMT) and performed workers' health examinations, Catalonia, Spain, 2011 - by type of Occupational Health Service (OHS)

\begin{tabular}{|c|c|c|c|c|c|}
\hline \multirow{2}{*}{ Question $^{1}$} & \multicolumn{3}{|c|}{$\begin{array}{l}\text { Type of OHS } \\
\text { (M) }\end{array}$} & \multirow{2}{*}{$\mathrm{MD}(95 \% \mathrm{CI})$} & \multirow{2}{*}{$\mathrm{PD}(95 \% \mathrm{CI})$} \\
\hline & $\begin{array}{c}\text { total } \\
(\mathrm{N}=168)\end{array}$ & $\begin{array}{l}\text { external } \\
(\mathrm{N}=80)\end{array}$ & $\begin{array}{l}\text { internal } \\
(\mathrm{N}=88)\end{array}$ & & \\
\hline 20. Working time [h/week] & 36.8 & 37.1 & 36.5 & $0.6(-1.2-2.4)$ & \\
\hline \multicolumn{6}{|l|}{ 21. Distribution of working time [\%] } \\
\hline time spent to health examinations & 56.3 & 66.0 & 47.5 & $18.5(12.4-24.5)^{*}$ & \\
\hline $\begin{array}{l}\text { time spent to collective health } \\
\text { surveillance }\end{array}$ & 17.4 & 18.0 & 16.8 & $1.2(-2.5-4.9)$ & \\
\hline time spent to other activities & 26.3 & 15.9 & 35.7 & $-19.7(-24.5-(-15.0))^{*}$ & \\
\hline 23. Health exams performed [n/week] & 34.2 & 49.6 & 19.7 & $29.9(24.2-35.5)^{*}$ & \\
\hline $\begin{array}{l}\text { 24. Fitness for work certificates supervised } \\
\text { [n/week] }\end{array}$ & 23.2 & 40.7 & 7.4 & $33.3(20.0-46.6)^{*}$ & \\
\hline 13. Workers per full-time physician [n] & 2425.0 & 3708.7 & 1352.7 & $2355.9(1726.9-2985.0)^{*}$ & \\
\hline 12. Workers per full-time nurse [n] & 2219.9 & 3480.0 & 1167.3 & $2312.7(1763.7-2861.7)^{*}$ & \\
\hline \multicolumn{6}{|l|}{$\begin{array}{l}\text { 25. Distribution of type of health } \\
\text { examinations [\%] }\end{array}$} \\
\hline pre-employment & 3.3 & 4.2 & 2.5 & $1.7(0.0-3.4)^{*}$ & \\
\hline pre-placement & 16.4 & 18.1 & 14.7 & $3.4(-1.0-7.7)$ & \\
\hline periodic & 65.5 & 68.0 & 63.1 & $5.0(-1.0-11.0)$ & \\
\hline return to work following sickness absence & 6.6 & 4.9 & 8.2 & $-3.3(-5.8-(-0.8))^{*}$ & \\
\hline at employer's request & 3.3 & 3.2 & 3.4 & $-0.2(-1.7-1.3)$ & \\
\hline at employee's request & 4.6 & 1.3 & 7.6 & $-6.3(-8.8-(-3.9))^{*}$ & \\
\hline post occupational & 0.4 & 0.3 & 0.5 & $-0.2(-0.6-0.2)$ & \\
\hline $\begin{array}{l}\text { 41. Health examinations that include } \\
\text { blood tests [\%] }\end{array}$ & 91.8 & 95.7 & 88.2 & $7.5(2.3-12.6)^{*}$ & \\
\hline $\begin{array}{l}\text { 42. Health examinations that include } \\
\text { urine tests [\%] }\end{array}$ & 75.7 & 87.3 & 65.1 & $22.1(11.4-32.8)^{*}$ & \\
\hline $\begin{array}{l}\text { 43. Blood and urine tests that are } \\
\text { job-specific [\%] }\end{array}$ & 41.3 & 33.5 & 48.5 & $-15.0(-26.6-(-3.5))^{*}$ & \\
\hline 44. Other tests that are job-specific [\%] & 68.2 & 71.9 & 64.8 & $7.2(-2.2-16.5)$ & \\
\hline $\begin{array}{l}\text { 60. Health examinations followed by fitness } \\
\text { for work certificate [\%] }\end{array}$ & 92.8 & 99.0 & 87.1 & $11.9(5.0-18.8)^{*}$ & \\
\hline $\begin{array}{l}\text { 61. Health exams followed by } \\
\text { recommendations to the company [\%] }\end{array}$ & 26.4 & 26.0 & 26.8 & $-0.8(-11.1-9.4)$ & \\
\hline \multicolumn{6}{|l|}{$\begin{array}{l}\text { 62. Distribution of fitness for work outcomes } \\
{[\%]}\end{array}$} \\
\hline fit & 87.3 & 85.5 & 88.9 & $-3.4(-7.0-0.2)$ & \\
\hline not fit & 1.3 & 1.5 & 1.2 & $0.3(-0.4-1.0)$ & \\
\hline fit with conditions/restrictions & 11.4 & 13.0 & 9.9 & $3.1(-0.2-6.4)$ & \\
\hline
\end{tabular}


Table 3. Time spent to health surveillance at the workplace, workload and tasks of occupational physicians, who were members of the Catalan Society of Safety and Occupational Medicine (SCSMT) and performed workers' health examinations, Catalonia, Spain, 2011 - by type of Occupational Health Service (OHS) - cont.

\begin{tabular}{|c|c|c|c|c|c|}
\hline \multirow{2}{*}{ Question $^{1}$} & \multicolumn{3}{|c|}{$\begin{array}{l}\text { Type of OHS } \\
\text { (M) }\end{array}$} & \multirow{2}{*}{$\mathrm{MD}(95 \% \mathrm{CI})$} & \multirow{2}{*}{ PD $(95 \%$ CI $)$} \\
\hline & $\begin{array}{c}\text { total } \\
(\mathrm{N}=168)\end{array}$ & $\begin{array}{l}\text { external } \\
(\mathrm{N}=80)\end{array}$ & $\begin{array}{l}\text { internal } \\
(\mathrm{N}=88)\end{array}$ & & \\
\hline $\begin{array}{l}\text { 66. Companies accept that some workers } \\
\text { might be fit with conditions [pts] }(0-10)\end{array}$ & 4.0 & 3.5 & 4.5 & $-1.0(-1.8-(-0.3))^{*}$ & \\
\hline $\begin{array}{l}\text { 14. Adequate and sufficient administrative } \\
\text { support }^{\mathrm{a}}[\%]\end{array}$ & 43.5 & 50.0 & 37.5 & & $12.5(-2.4-26.7)$ \\
\hline $\begin{array}{l}\text { 18. Accessibility of OHS for workers } \\
\text { (consultations outside health } \\
\text { exams })^{\mathrm{b}}[\%]\end{array}$ & 59.4 & 25.6 & 89.7 & & $-64.0(-73.7-(-50.6))^{*}$ \\
\hline \multicolumn{6}{|l|}{ 19. Barriers to accessibility of OHS [\%] } \\
\hline unawareness of its functions ${ }^{c}$ & 65.5 & 88.5 & 44.8 & & $43.6(29.9-55.0)^{*}$ \\
\hline distrust $^{c}$ & 46.7 & 62.8 & 32.2 & & $30.6(15.4-43.9)^{*}$ \\
\hline timings/distance ${ }^{\mathrm{c}}$ & 34.5 & 43.6 & 26.4 & & $17.2(2.6-30.9)^{*}$ \\
\hline $\begin{array}{l}\text { 45. Physician never/hardly ever has } \\
\text { difficulty asking for job-specific } \\
\text { tests }^{\mathrm{d}}[\%]\end{array}$ & 40.5 & 23.3 & 56.3 & & $-33.0(-46.2-(-17.6))$ \\
\hline $\begin{array}{l}\text { 65. Some workers avoid health exams } \\
\text { for fear of a "not fit" or "fit with } \\
\text { conditions" certificate (yes) }{ }^{\mathrm{a}}[\%]\end{array}$ & 43.6 & 60.6 & 28.2 & & $32.4(16.5-46.1)^{*}$ \\
\hline
\end{tabular}

${ }^{1}$ Questions were grouped with a research logic, but their original numbering (as in Table 1) was left.

PD - prevalence difference.

Answer to the questionnaire: ${ }^{\mathrm{a}} \mathrm{yes} ;{ }^{\mathrm{b}}$ always/nearly always or often; ${ }^{\mathrm{c}}$ strong or significant; ${ }^{\mathrm{d}}$ never/hardly ever.

* Statistically significant difference.

Other abbreviations as in Table 2.

If additional tests/investigations specific to occupational hazards (laboratory tests or others), not routinely included in the usual health examinations, had to be requested, physicians in external services had significantly more difficulty obtaining them due to administrative/bureaucratic and/or commercial/financial reasons.

These health examinations were nearly always followed by a fitness-for-work certificate (99\% external, $87 \%$ internal) with no differences in the outcome by type of OHS: $87.3 \%$ of workers were declared fit, $1.3 \%$ not fit, and $11.4 \%$ fit with conditions/restrictions.

As shown in the Table 4, there were shortcomings in the availability of clinical and exposure information at the moment of performing the health examination, and the bivariate analysis showed significantly lower percentages in all items for the external OHS.

Regarding awareness of sickness absence data, $6 \%$ of physicians from the external OHS had knowledge of workrelated absences, and 3\% had knowledge of non-workrelated absences, compared to $75 \%$ and $49 \%$, respectively from internal services. None of the physicians from external services participated always/nearly always in the investigation of occupational injuries, whilst $36 \%$ in internal ones did so; and regarding occupational diseases, $4 \%$ of physicians in external services and $54 \%$ in internal ones participated in the investigations always/nearly always. 
Table 4. Relevant input, procedural and outcome aspects of medical practice of occupational physicians, who were members of the Catalan Society of Safety and Occupational Medicine and performed workers' health examinations, Catalonia, Spain, 2011 by type of Occupational Health Service (OHS)

\begin{tabular}{|c|c|c|c|c|}
\hline \multirow{2}{*}{ Question $^{1}$} & \multicolumn{3}{|c|}{$\begin{array}{l}\text { Type of OHS } \\
{[\%]}\end{array}$} & \multirow{2}{*}{$\mathrm{PD}(95 \% \mathrm{CI})$} \\
\hline & $\begin{array}{c}\text { total } \\
(\mathrm{N}=168)\end{array}$ & $\begin{array}{l}\text { external } \\
(\mathrm{N}=80)\end{array}$ & $\begin{array}{l}\text { internal } \\
(\mathrm{N}=88)\end{array}$ & \\
\hline \multicolumn{5}{|l|}{ 26. Clinical information available during health examinations } \\
\hline medical record ${ }^{\mathrm{a}}$ & 67.5 & 54.1 & 80.0 & $-25.9(-39.4-(-11.1))^{*}$ \\
\hline previous biological monitoring or other tests if applicable ${ }^{\mathrm{a}}$ & 60.4 & 48.6 & 71.3 & $-22.6(-36.7-(-7.1))^{*}$ \\
\hline $\begin{array}{l}\text { previous medical/health surveillance data from other OHS } \\
\text { if applicable }{ }^{\mathrm{a}}\end{array}$ & 9.9 & 4.1 & 15.4 & $-11.3(-21.3-(-1.7))^{*}$ \\
\hline medical reports from other health professionals if applicable ${ }^{\mathrm{a}}$ & 7.8 & 2.7 & 12.5 & $-9.8(-19.0-(-1.1))^{*}$ \\
\hline $\begin{array}{l}\text { employee never/hardly ever is the only source of clinical } \\
\text { information }^{\text {b }}\end{array}$ & 18.2 & 9.5 & 26.3 & $-16.8(-28.4-(-4.6))^{*}$ \\
\hline 28. Physician requests additional clinical information if necessary ${ }^{c}$ & 79.9 & 77.0 & 82.5 & $-5.5(-18.2-7.2)$ \\
\hline \multicolumn{5}{|l|}{ 36. Exposure information available during health examinations } \\
\hline job title ${ }^{\mathrm{a}}$ & 80.4 & 75.3 & 85.0 & $-9.7(-22.3-3.0)$ \\
\hline job description ${ }^{\mathrm{a}}$ & 56.2 & 45.2 & 66.3 & $-21.0(-35.4-(-5.3))^{*}$ \\
\hline risk evaluation ${ }^{\mathrm{a}}$ & 53.6 & 45.2 & 61.3 & $-16.0(-30.8-(-0.3))^{*}$ \\
\hline hygiene and environmental measures if applicable ${ }^{\mathrm{a}}$ & 35.3 & 17.8 & 51.3 & $-33.4(-46.2-(-18.5)) *$ \\
\hline personal protective equipment required if applicable $\mathrm{a}^{\mathrm{a}}$ & 42.5 & 28.8 & 55.0 & $-26.2(-40.1-(-10.6))^{*}$ \\
\hline direct knowledge of the workplace (visited) ${ }^{\mathrm{a}}$ & 22.9 & 2.7 & 41.3 & $-38.5(-49.6-(-26.3))^{*}$ \\
\hline $\begin{array}{l}\text { never/hardly ever, have to rely exclusively on the information } \\
\text { provided by worker }{ }^{b}\end{array}$ & 30.7 & 19.2 & 41.3 & $-22.1(-35.3-(-7.5))^{*}$ \\
\hline \multicolumn{5}{|l|}{ 29. Easiness for obtaining information from: } \\
\hline primary care (National Health System) ${ }^{\mathrm{d}}$ & 41.8 & 44.6 & 39.4 & $5.2(-11.9-22.2)$ \\
\hline specialists (National Health System) ${ }^{\mathrm{d}}$ & 34.4 & 25.0 & 42.4 & $-17.4(-32.7-(-0.5))^{*}$ \\
\hline occupational diseases and injuries insurers ${ }^{\mathrm{d}}$ & 49.6 & 36.4 & 60.9 & $-24.6(-40.4-(-6.6))^{*}$ \\
\hline incapacity benefit inspectors body ${ }^{\mathrm{d}}$ & 21.4 & 9.3 & 31.7 & $-22.5(-35.8-(-7.8))^{*}$ \\
\hline occupational support unit for family physicians ${ }^{\mathrm{d}}$ & 32.4 & 22.6 & 41.4 & $-18.7(-34.5-(-1.3))^{*}$ \\
\hline other health professionals (e.g., private) ${ }^{\mathrm{d}}$ & 62.0 & 56.3 & 66.7 & $-10.4(-28.0-7.7)$ \\
\hline \multicolumn{5}{|l|}{$\begin{array}{l}\text { Knowledge of other relevant health } \\
\text { and injuries information }\end{array}$} \\
\hline 31. Non work-related sickness absence ${ }^{a}$ & 26.8 & 2.7 & 48.8 & $-46.0(-56.9-(-33.4)) *$ \\
\hline 32. Work related sickness absence ${ }^{a}$ & 41.8 & 5.5 & 75.0 & $-69.5(-78.4-(-56.5)) *$ \\
\hline 33. Occupational injuries or diseases without sickness absence ${ }^{a}$ & 39.2 & 2.7 & 72.5 & $-69.8(-78.6-(-57.2)) *$ \\
\hline 34. Investigation of occupational injuries ${ }^{a}$ & 19.0 & 0.0 & 36.3 & $-36.3(-47.2-(-25.4))^{*}$ \\
\hline 35. Investigation of occupational and work related diseases ${ }^{a}$ & 30.1 & 4.1 & 53.8 & $-49.6(-60.5-(-36.6))^{*}$ \\
\hline \multicolumn{5}{|l|}{$\begin{array}{l}\text { Multidisciplinary team work } \\
\text { and workplace visits }\end{array}$} \\
\hline 38. Communication with risk prevention specialists ${ }^{\mathrm{e}}$ & 50.3 & 34.2 & 65.0 & $-30.8(-44.5-(-14.9)))^{*}$ \\
\hline
\end{tabular}


Table 4. Relevant input, procedural and outcome aspects of medical practice of occupational physicians, who were members of the Catalan Society of Safety and Occupational Medicine and performed workers' health examinations, Catalonia, Spain, 2011 by type of Occupational Health Service (OHS) - cont.

\begin{tabular}{|c|c|c|c|c|}
\hline \multirow{2}{*}{ Question $^{1}$} & \multicolumn{3}{|c|}{$\begin{array}{l}\text { Type of OHS } \\
{[\%]}\end{array}$} & \multirow{2}{*}{$\mathrm{PD}(95 \% \mathrm{CI})$} \\
\hline & $\begin{array}{c}\text { total } \\
(\mathrm{N}=168)\end{array}$ & $\begin{array}{l}\text { external } \\
(\mathrm{N}=80)\end{array}$ & $\begin{array}{l}\text { internal } \\
(\mathrm{N}=88)\end{array}$ & \\
\hline $\begin{array}{l}\text { 58. Information on health surveillance to risk prevention specialists } \\
\text { (preventive purpose) }^{\mathrm{a}}\end{array}$ & 30.7 & 15.5 & 44.3 & $-28.8(-41.6-(-14.2))^{*}$ \\
\hline 39. Frequency of workplace visits ${ }^{\mathrm{f}}$ & 42.5 & 19.2 & 63.8 & $-44.6(-56.8-(-29.4))^{*}$ \\
\hline \multicolumn{5}{|l|}{$\begin{array}{l}\text { Communication of results to worker, company } \\
\text { and insurers. Case management }\end{array}$} \\
\hline 50. Information to the worker about his/her general health ${ }^{\mathrm{a}}$ & 92.1 & 90.3 & 93.7 & $-3.4(-13.1-5.7)$ \\
\hline 52. Information to the worker about his/her health in relation to work ${ }^{\mathrm{a}}$ & 61.6 & 52.8 & 69.6 & $-16.8(-31.4-(-1.3))^{*}$ \\
\hline 56. Recommendations to the companies ${ }^{\mathrm{a}}$ & 24.5 & 16.7 & 31.6 & $-15.0(-27.9-(-1.2))^{*}$ \\
\hline 57. Recommendations are taken into consideration ${ }^{g}$ & 46.0 & 23.9 & 65.8 & $-41.9(-54.6-(-26.3)) *$ \\
\hline $\begin{array}{l}\text { 53. Referral of suspected cases to occupational diseases and injuries } \\
\text { insurers }^{\mathrm{a}}\end{array}$ & 51.7 & 41.7 & 60.8 & $-19.1(-33.7-(-3.1))^{*}$ \\
\hline \multicolumn{5}{|l|}{$\begin{array}{l}\text { Professional independence the participating occupational physicians } \\
\text { never/hardly ever avoid communicating: }\end{array}$} \\
\hline $\begin{array}{l}\text { 54. Suspected professional diseases due to possible negative } \\
\text { consequences to worker }{ }^{\mathrm{b}}\end{array}$ & 54.3 & 44.4 & 63.3 & $-18.8(-33.5-(-2.9))^{*}$ \\
\hline $\begin{array}{l}\text { 55. Suspected professional diseases due to perceived direct or indirect } \\
\text { pressure }^{\mathrm{b}}\end{array}$ & 66.2 & 58.3 & 73.4 & $-15.1(-29.4-0.0)^{*}$ \\
\hline $\begin{array}{l}\text { 63. Fits with conditions due to possible negative consequences for } \\
\text { the worker }{ }^{\mathrm{b}}\end{array}$ & 45.6 & 49.3 & 42.3 & $7.0(-8.8-22.4)$ \\
\hline 64. Fits with conditions due to perceived direct or indirect pressure ${ }^{b}$ & 67.8 & 67.6 & 67.9 & $-0.3(-15.2-14.3)$ \\
\hline
\end{tabular}

${ }^{1}$ Questions were grouped with a research logic, but their original numbering (as in Table 1) was left.

Answer to the questionnaire: ${ }^{\mathrm{a}}$ always/nearly always; ${ }^{\mathrm{b}}$ never/hardly ever; ${ }^{\mathrm{c}}$ yes; ${ }^{\mathrm{d}}$ very easy or easy; ${ }^{\mathrm{e}}$ very good or good; ${ }^{\mathrm{f}}$ systematic visits or visits often; ${ }^{\mathrm{g}}$ always/nearly always or often.

* Statistically significant difference.

Other abbreviations as in Tables 2 and 3.

Fewer than $2 / 3$ of physicians always/nearly always referred workers to occupational injuries and diseases insurers for diagnostic confirmation and treatment if, following a health examination, an occupational or work-related disease was suspected, and this referral rate was significantly lower in the external OHS (42\% vs. $61 \%$ in internal services). Physicians made recommendations to the companies following health examinations but they were reportedly taken into account by companies in fewer than $2 / 3$ of the cases.
Finally, the Table 4 also shows the potential threats to professional independence reported by occupational physicians.

\section{DISCUSSION}

A high percentage of occupational physicians have limitations in their current medical practice. These shortcomings include the availability of clinical and occupational exposure information at the moment of performing the health examination, the job-specificity of health examinations and 
tests, the early detection and appropriate management of suspected occupational diseases, and threats to the professional independence of physicians. The situation in the external OHS is worse, remarkably in regard to knowledge of occupational and non-occupational sickness absence data, participation in the investigation of occupational injuries and diseases, and accessibility for workers to the OHS.

Regarding clinical information, the situation was worse for externally generated data, which could be explained by poor coordination and communication with the National Health Service and the occupational injuries and diseases insurers, and a lack of continuity of records when the worker changes jobs or the employer contracts different OHS. The limitations in exposure information (e.g., job description, risk evaluation, environmental measurements), are of particular concern because without it occupational medicine loses all meaning. They could be due to inefficient communication with other members of the OHS and to an excess of bureaucratization (e.g., long and uninformative/unpractical risk evaluations). This together with the low job-specificity of routinely used tests, and the difficulties for requesting additional tests when needed, point towards general health check-ups rather than the intended job-specific health examinations.

In this scenario, $85 \%$ of occupational health professionals participating in a previous study [14] felt that the highly trained Catalan occupational physicians and nurses are overqualified for the range of activities they currently perform and the way they do them. The fact that the number of workers assigned is practically the same for nurses and doctors is consistent with the structure in Spain, regulations recommending that the "basic occupational unit" is constituted by 1 doctor and 1 nurse for every 2000 workers [16]. More efficient structures could be promoted, and a majority of occupational health professionals are in favor of giving a major role in health surveillance to specialist occupational nurses, increasing their professional autonomy [14].
Accessibility is an important problem for the external OHS. Most enterprises in many countries, including Spain, are small and medium, often dispersed geographically. Physicians from the external OHS are located away from the workplaces, and their contact with workers is often limited to health examinations. On the contrary, accessibility is very good in the internal OHS, which together with a higher rate of health examinations for return to work after sick leave and at a worker's request could, at least partially, compensate the rest of the findings, therefore improving the possibilities of early detection of health problems related to work and identification of especially vulnerable workers in the internal OHS. When asked about possible barriers for accessibility, physicians from both types of the OHS agreed that lack of awareness of the functions of the OHS was the most important.

The fact that health examinations are virtually always followed by a fitness-for-work certificate, that is issued regardless of the job and the associated risks, might have the unintended effect of being detrimental to workers. Given that, according to participants, companies are not very receptive to accept workers "fit for work with conditions," some workers might decide to avoid accessing the OHS for fear of being declared "not fit or fit with conditions."

Another source of threat to professional independence and detriment for the worker could lay, paradoxically, in one of the main objectives of these examinations: the early diagnosis and treatment of occupational and work-related diseases. Only $42 \%$ of physicians from external services, and $61 \%$ in internal services declared that they always/ nearly always referred suspected cases to occupational injuries and diseases insurers, whose responsibility was, as previously explained, the diagnosis, treatment and official reporting of occupational diseases and injuries in Spain. One possible explanation might be the fact that the regulatory framework in Spain determines economic compensation and corporate responsibilities for companies in case of recognition of occupational injury or disease. 
In occupational health, there are interactions amongst many partners, sometimes with conflicting interests. Although the code of ethics of the International Commission of Occupational Health states in its basic principles that "occupational health professionals are experts who must enjoy full professional independence in the execution of their functions" [17], it cannot be guaranteed that this is always the case [18].

The high number of health examinations performed (4 million annually in Spain), most of them including blood and urine tests despite their acknowledged low job-specificity, could be explained by a badly understood concept of "health surveillance," by cultural and historical factors [19] (on occasions understood by workers and their representatives as "acquired rights," and by employers as something "tangible" in return for their economic investment on health surveillance or as a means of, supposedly, formally complying with their legal requirements), and by economic interests by the OHS themselves. At an approximate cost of 50-60 euro per health examination [20], direct costs to Spanish companies would amount to the minimum of 200 million euro per year, and thousands of millions of euro if extrapolated to Europe.

Indirect costs for companies are difficult to calculate but they include lost working hours, adjustments to maintain production schedules, and travel time and expenses. There is also an associated increase in health expenditures by the National Health System due to consultations with family physicians, and repetitions of examinations and tests due to the unavoidable large number of false positives generated. This situation is not unique to Catalonia and Spain. Health examinations for workers are extensively performed in many countries, either in the context of fitness-for-work examinations - mainly at pre-employment/pre-placement; as part of health surveillance - mostly periodic and often linked to fitness-for-work certification; or as general health checks.

In a survey performed by the Occupational Medicine Section of the European Union of Medical Special- ists (UEMS) to official representatives from 25 European countries, 17 declared that employers in their countries were obliged to offer health examinations to all their employees; moreover, in 12 of these countries, it was also compulsory for employees to undertake the examinations [21].

The results of this study lead one to think that the health examinations analyzed are mainly generalist, and we should reflect on whether it is justified to do them at the expense of the employer and in a country with a robust and universal public health system, already covering for the screening, diagnosis and treatment of not work-related diseases. It seems clear that we are over-testing. But are we, at the same time, insufficiently or incorrectly testing in other areas where correct testing is very important? And, is all this to the detriment of other preventive and non-preventive activities that occupational medicine may offer?

In any case, "health examinations cannot protect workers against health hazards, and they cannot substitute for appropriate control measures, which have the first priority in the hierarchy of actions. And if prevention has proven successful, fewer examinations are needed" [22].

\section{Strengths and limitations}

This is the first study of its kind in Spain. Other strengths include the wide sample of occupational physicians, representing $40 \%$ of the reference population, and the fact that the information comes directly from the physicians themselves, who are the ones who know best what their usual practice is like.

Selection bias cannot be discarded as a limitation. On the one hand, the medical practice of the physicians who did not participate in this study may have been different from that of the respondents. The database of the SCSMT did not include data on exact tasks. Therefore, no comparison was possible between participating and non-participating physicians who performed health examinations in their usual practice. However, no significant differences 
were observed for socio-demographic or professional characteristics between the sample and SCSMT members as a whole (Table 2) or between responders and nonresponders in a broader survey conducted simultaneously to SCSMT members, which included the participants of this study [14], so there were no reasons to think that it would be different in this case.

On the other hand, the medical practice of the physicians from the SCSMT may have been different from that of physicians who were not members. In fact, physicians from the external OHS are underrepresented in the SCSMT, which is reflected in the distribution of the participants in this study. However, our knowledge of the Catalan situation and the results from a survey conducted in 2007 by the SCSMT [23], point to the fact that the professional situation and working conditions of those who are not members of the SCSMT are frequently worse, and, presumably, their practice would be too. This point, combined with the fact that our study shows that practice in external services has bigger limitations than in internal ones, leads one to think that the underrepresentation of professionals from the external OHS and a potential selection bias by the choice of the study population, would only add to underestimate the real situation in Catalonia.

Given the limitations of the study we have to be cautious in extrapolating results. However, in the worst possible scenario in relation to representativeness, the situation described by the participants in the study would correspond to $40.3 \%$ of the total estimated physicians performing workers' health surveillance activities and health examinations in Catalonia. Although the final error achieved was $\pm 7.5 \%$, this reduction in the precision of estimates did not change the conclusions, as the preventive usefulness would have been compromised even if the extreme range values of confidence intervals had been chosen.

Furthermore, given that health and safety laws and the labour inspectorate are common in Spain, and companies and occupational health services share similar practices and procedures, especially in the case of external OHS, most of which are large nation-wide corporations, it would be reasonable to think that our results might describe the situation in other parts of Spain, too.

How the results in Catalonia may be extrapolated to other countries is difficult to know but ruling out similar practices could be indicated in those with comparable scenarios in relation to routine health examinations.

Our results are in agreement with the best available scientific evidence, showing that the preventive usefulness of indiscriminate health examinations is highly questionable, both for the general population $[24,25]$ and for the working population [26].

A Belgian survey of occupational physicians [27] showed results consistent with ours: physicians complained of being constricted by a legal framework leading to excessive periodic examinations at the expense of other forms of prevention. Those physicians in favor of periodic examinations stated that their content should be improved. A French qualitative study of occupational health doctors and workers also concluded that "occupational health practice often falls into an institutional framework that prioritizes medical examinations over the improvement of environmental and organizational conditions, worker health protection and, when needed, promotion of workplace adaptations" [28].

\section{CONCLUSIONS}

This study raises serious concerns about the occupational preventive usefulness of workers' health examinations as they are currently performed, given the shortcomings found regarding the clinical and exposure information available to the physicians who perform them, the jobspecificity of the examinations and tests, and the early detection and appropriate management of suspected occupational diseases. The situation is worse in external occupational health services that cover the great majority of the Catalan workers. This in turn questions the appropri- 
ateness of our health surveillance system, based primarily on these examinations.

Professionals alongside health and safety institutions and stakeholders should promote the rationalization of this system, following the technical criteria of need, relevance, scientific validity and effectiveness [22], whilst ensuring that its ultimate goal of improving the health and safety of workers in relation to work is fulfilled. Other countries with surveillance systems similar to ours might be encouraged by our results to assess how their practices fit the intended purpose.

\section{ACKNOWLEDGMENTS}

We would like to thank the professionals of the Catalan Society of Safety and Occupational Medicine who participated in this survey and the board of the Society for their support.

\section{REFERENCES}

1. Technical and ethical guidelines for workers' health surveillance. Geneva: International Labour Office; 1998.

2. [Spanish law 31/1995 of 8th November 1995 on occupational risk prevention, Spanish Law]. Spanish.

3. Council Directive of 89/391/EEC of 12 June 1989 on the introduction of measures to encourage improvements in the safety and health of workers at work. Off J Eur Communities L 183 (Jun 29, 1989).

4. [Royal Decree 39/1997 of 17 January approving the regulations for Prevention Services, Spanish Royal Decree]. Spanish.

5. Government of Catalonia. Ministry of Labour. [Managing risk prevention in companies 2014] [Internet]. Barcelona: The Ministry; 2015 [cited 2016 Mar 24]. Available from: http://empresa.gencat.cat/web/.content/03_-_centre_de_documentacio/documents/01_-_publicacions/06_-_seguretat_i_ salut_laboral/arxius/INFORME_gestio_PRL_empreses_ CAT_2004_2015.pdf. Catalan.

6. De Montserrat J, de Peray JL, Fernández R, Juanola E, Molinero E, Pitarque S. [Analysis of the reports of occupational health services in Catalonia in 2013] [Internet]. Barcelona:
Ministry of Labour. Government of Catalonia; 2015 [cited 2016 Mar 24]. Available from: http://empresa.gencat. cat/web/.content $/ 03$ ___centre_de_documentacio/documents/01_-_publicacions/06_-_seguretat_i_salut_laboral/ arxius/estudi_memories_sprl_2010.pdf. Catalan.

7. [National Statistics Institute] [Internet]. Madrid: The Institute; 2013 [cited 2015 Sep 4]. [Occupied salaried population in 2013]. Available from: http://www.ine.es. Spanish.

8. Andermann A, Blancquaert I, Beauchamp S, Déry V. Revisiting Wilson and Jungner in the genomic age: A review of screening criteria over the past 40 years. Bull World Health Organ. 2008;86(4):317-9, https://doi.org/10.2471/BLT.07.050112.

9. Wilson JMG, Jungner G. Principles and practice of mass screening for disease [Internet]. Geneva: World Health Organization; 1968 [cited 2015 May 15]. Available from: http://apps. who.int/iris/bitstream/10665/37650/1/WHO_PHP_34.pdf.

10. Evans I, Thornton H, Chalmers I, Glasziou P. Earlier is not necessarily better [Internet]. 2nd ed. London: Pinter \& Martin; 2011 [cited 2015 May 15]. Available from: http://www. ncbi.nlm.nih.gov/books/NBK66204.

11. Delclós J, Artazcoz L. [Cancer screening in occupational health: Detection or distraction?]. Arch Prev Riesgos Labor. 2013;16(4):161-3, https://doi.org/10.12961/aprl.2013.16.4.01. Spanish.

12. Glasziou P, Moynihan R, Richards T, Godlee F. Too much medicine; too little care. Br Med J. 2013;347(2):4247, https://doi.org/10.1136/bmj.f4247.

13. McCartney M. The patient paradox: Why sexed up medicine is bad for your health. London: Pinter \& Martin; 2012.

14. Rodríguez-Jareño MC, Molinero E, de Montserrat J, Vallès $\mathrm{A}$, Aymerich M. How much do workers' health examinations add to health and safety at the workplace? Occupational preventive usefulness of routine health examinations. Gac Sanit. 2015;29(4):266-73, https://doi.org/10.1016/j.gaceta.2014.11.001.

15. Domenech JM, Granero R. Macro !NP for SPSS Statistics. Sample size: Estimation of population proportion [computer programme] [Internet]. Bellaterra: Autonomous 
University of Barcelona; 2008 [cited 2015 Apr 11]. Available from: http://www.metodo.uab.cat/macros.htm.

16. [Royal Decree 843/2011 of 17 June that establishes the basic criteria concerning the organization of resources to develop health activity of prevention services, Spanish Royal Decree]. Spanish.

17. International Commission on Occupational Health. International code of ethics for occupational health professionals [Internet]. 3rd ed. Rome: The Commission; 2014 [cited 2015 May 15]. Available from: http://www.icohweb.org/site/multimedia/code_of_ethics/code-of-ethics-en.pdf.

18. Ladou J. Occupational medicine. The case for reform. Am J Prev Med. 2005;28(4):396-402, https://doi.org/10.1016/ j.amepre.2004.12.016.

19. Pachman J. Evidence base for pre-employment medical screening. Bull World Health Organ. 2009;87(7):529-34, https://doi.org/10.2471/BLT.08.052605.

20. CincoDías; Pascual R. [Internet]. Madrid: CincoDías; 2012 [cited 2015 Sep 24]. [Some prevention services cut prices by 30\%]. Available from: http://cincodias.com/cincodias/ 2012/07/17/economia/1342504587_850215.html. Spanish.

21. Rodriguez-Jareño MC, Kurent M, Romih D, Škerjanc A. Tasks of specialists in occupational medicine in Europe [Internet]. UEMS Section of Occupational Medicine; 2015 [cited 2015 Nov 2]. Available from: http://www.uems-occupationalmedicine.org/sites/default/files/Meetings/2015_Sibenic/tasks_of_op_in_europe__uems_girona_mr.pdf.

22. Encyclopaedia of Occupational Health and Safety; Rantanen J, Fedotov IA [Internet]. Geneva: International Labour Organization; 2012 [cited 2015 Sep 24]. Standards, principles and approaches in occupational health services.
Available from: http://www.iloencyclopaedia.org/component/k2/item/154-standards-principles-and-approaches-inoccupational-health-services.

23. Rodríguez R, Ramírez I, Ripoll R, García A, Sabaté J. [Survey of the situation of Catalan occupational health professionals 2007]. Barcelona: Catalan Society of Safety and Occupational Medicine; 2008. Catalan.

24. Krogsbøll LT, Jørgensen KJ, Grønhøj LC, Gøtzsche PC. General health checks in adults for reducing morbidity and mortality from disease: Cochrane systematic review and meta-analysis. Br Med J. 2012;345:e7191, https://doi. org/10.1136/bmj.e7191.

25. Holland W. Periodic health examination: A brief history and critical assessment. Eurohealth (Lond) [Internet]. 2009 [cited 2015 Oct 31];15(4):16-20. Available from: http://www.euro. who.int/_data/assets/pdf_file/0011/83990/Eurohealth15_4.pdf. 26. Mahmud N, Schonstein E, Schaafsma F, Lehtola MM, Fassier JB, Reneman MF, et al. Pre-employment examinations for preventing occupational injury and disease in workers. Cochrane Database Syst Rev. 2010;(12), https://doi. org/10.1002/14651858.CD008881.

27. [Professional Association of Belgian Occupational Physicians] [Internet]. Brussels: Federal Public Service: Employment, Labor and Social Dialogue; 2012 [cited 2015 July 24]. [Survey of Belgian occupational physicians September 2009]. Available from: http://www.emploi.belgique.be/moduleDefault.aspx?id $=29502$. French and Dutch.

28. Bachet D. [Professional practices under pressure. Clinical examination of employees in occupational medicine]. Actes Rech Sci Soc. 2011;188:54-69, https://doi.org/10.3917/ arss.188.0054. French.

This work is available in Open Access model and licensed under a Creative Commons Attribution-NonCommercial 3.0 Poland License - http://creativecommons.org/ licenses/by-nc/3.0/pl/deed.en. 